\title{
Voting in Local Political Elections by Urban Chinese Middle Class: Does Housing Matter?
}

\author{
Liyun $\mathrm{Wu}^{1} \&$ Gang Wang ${ }^{2}$ \\ ${ }^{1}$ The Ethelyn R. Strong School of Social Work, Norfolk State University, United States \\ ${ }^{2}$ Department of Political Science, University of Zürich, Switzerland \\ Correspondence: Liyun Wu, The Ethelyn R. Strong School of Social Work, Norfolk State University, 700 Park \\ Ave, Norfolk, VA, United States. Tel: 757-823-9037. E-mail: lwu@nsu.edu
}

Received: December 28, 2015 Accepted: January 8, 2016 Online Published: February 4, 2016

doi:10.20849/ajsss.v1i1.5

URL: http://dx.doi.org/10.20849/ajsss.v1i1.5

\begin{abstract}
This paper examines the impact of types of housing on the tendency to engage in neighborhood-level political participation among urban residents in China, using 2005 China General Social Survey. Four types of housing were discussed: commercial housing; previously state-owned (work unit) housing; old neighborhood; and other types of housing (i.e. migration housing). Two indicators of local political participation were presented in the form of Local People's Congress elections and Residents' Committee elections. Using multivariate logistic regression analysis, the authors found that types of housing had strong implications for voting in local elections among Chinese urban residents. First, the likelihood of voting in two local elections was lowest among residents living in commercial housing, and the highest in old neighborhoods. Second, participation in community-led venues (i.e. cultural events) enhanced the voting rate among residents living in commercial housing. Results highlight the importance of the sweeping housing reform in urban neighborhoods to local political participation in contemporary China, and the changing relationship between state and society. Although rapid economic reform has diversified and alienated the neighborhood, community-led civic activities can reunify the residents and enhance their local political participation. This effect was more significant among the young, college-educated, high-income middle class.
\end{abstract}

Keywords: China, middle class, local political participation, community participation, state-society relationship, modernization theory

\section{Introduction}

With the rapid economic growth occurring since the 1978 economic reform, China has been experiencing drastic urbanization and urban development, as manifested by rising housing units, steady inflow of rural migrants, accelerated urban renewal and expansion, increased labor mobility, cost of living, life expectancy, educational attainment, and the widen income gap (Doepke \& Zilibotti, 2007; Forrest \& Yip, 2007). Among those social changes, housing reform is one of the most challenging areas. During the Mao era, most urban residents lived in state housing or work-unit compounds with low rate of homeownership, paying no or highly subsidized rental fees. During 1980-2010, the housing sector emerged and gained momentum in terms of its size, complexity, and socio-political prominence, with the rate of homeownership growing from 20 to 70 percent, and per capita living space increasing from $4 \mathrm{~m}^{2}$ to $29 \mathrm{~m}^{2}$ (Huang, 2012). During the past decade since 2003, ordinary commodity housing has been identified as the main housing form by the central government, and massive construction and consumption of commercial housing served as the catalyst to economic growth.

Urbanization also transformed Chinese society by promoting a rising middle class, which has steadily emerged as change agents for current socio-political development. Although the definition of the term "middle class" is ambiguous in social science literature (Tang, 2011), it is recognized nevertheless that this group as a whole is seen as representing new values, new types of behaviors, new ideas, and new life styles (Hefele \& Dittrich, 2011). Defining China's middle class proves to be more difficult because China has a disparate population, imbalanced regional development, and distinct cost of living across cities and provinces. Attempts have been made to estimate the size of the middle class in China. It was estimated that it was a wide range from 200 million to approximately half a billion based on various kinds of criteria (Hurtado, 2014; United Nations, 2014). Despite the debates of the size and definitions of middle class, there has been as rise of a loosely defined middle 
class that has undoubtedly changed the Chinese society not only economically but also socio-politically.

A considerable amount of research has focused on the rising middle class during economic transition, and has built the connections between sustained economic development, political democratization and an expanded middle class (Barro, 1999; Boix \& Stokes, 2003; Bollen, 1983; Londregan \& Poole, 1996). According to the modernization theory, economic growth can predict positive change in democracy in developing countries (Huntington, 1991). With rapid economic development, the modern Chinese society has been transformed to become more diversified and multi-faceted. The middle class will become more politically autonomous by demanding a greater voice in political decision-making and civic engagement (Fukuyama, 1993; Glassman, 1995). However, the empirical evidence is mixed regarding the dynamic relationship between economic modernization and political democratization. On the one hand, studies show that Chinese middle class collectively demonstrated a higher democratic orientation compared to those who were categorized as lower class, which was defined by occupation or by self-identification, and not by income level (Tang, Woods \& Zhao, 2009). Chen and $\mathrm{Lu}$ (2006) also echoed this conclusion. They found that urban middle class members in Beijing were more likely to support the more democratic self-government, compared to other social stratum. On the other hand, competing research revealed contradictory findings between democracy and attitudes of the Chinese middle class. Chen and his colleague investigated private entrepreneurs, a subcategory of the middle class, and found that they were resistant to regime change and in favor of maintaining the status quo (Chen \& Dickson, 2008).

There are two major explanations of the ambiguous role of the middle class in developing countries. One explanation is related to the dependent nature of this group, which emphasizes the connection between their prosperity and their vested interest in pro-market government policies (Jones, 1998; Muller, 1997). Many members of the Chinese middle class work in the public sector or in companies with close ties to government agencies. Their financial success is perceived to be dependent on the stability of the current political institution. For example, intellectuals such as teachers and professors with college or above education have gained substantially from the recent pay increase policy initiated by the government (Unger, 2006). Private entrepreneurs have been granted the opportunity to join the Chinese Communist Party (CCP) and become involved in local political decision-making since 2001 on the basis of the "Theory of the Three Representatives." Another explanation has focused on the Chinese middle class's desire to maintain the status quo and their reluctance to institute changes. As the urban middle class members benefited from the reform, and enjoyed advantageous socioeconomic status, they avoided any unpredictable events that interrupted or caused them to lose their social status into the hands of the mass rural population (Unger, 2006).

This study is an effort to fill the gap of the literature by investigating to what extent the Chinese middle class participates in democratic actions at the community-level. Democratic actions were approximated by two indicators: the local People's Congress election and the local Residents' Committee election. The community was defined according to types of housing residing in different residential properties. Four types of housing were included- commercial apartment building, work unit housing, old neighborhoods, and other types (e.g. urban renewal, migration housing, relocation housing). There were two hypotheses. Hypothesis one was that types of housing would be significantly associated with local political participation. Among the different housing units being investigated, urban residents living in commercial apartments were expected to be less likely to be involved in the local People's Congress election and the local Residents' Committee's election, compared to those living in old neighborhoods. Second, among the subsample group living in commercial apartments, community-led cultural events were expected to be related to their local political participation.

The organization of this study is as follows. First, the background information and literature review of China's urban housing reform, local political participation, local community participation, and rising middle class were presented. Second, the research design, data source, measurements, and analysis plan were explained. Third, the descriptive characteristics of the sample were reported. Fourth, results from multivariate analyses, including the relationships between housing types and local political participation, community-led cultural events and local political participation were reported. Finally, conclusions were made along with social and political implications of the findings.

\section{Background and Literature Review}

\subsection{Urban Housing in China}

In contemporary China, there are four types of urban housing: commercial housing; work unit ownership housing; old neighborhoods; or other types (e.g. urban renewal or old city redevelopment housing, migration housing, relocation housing). These four types of housing, however, play a different role in the housing market 
and their residents have different characteristics which were historically shaped by government policies.

During the pre-reform period prior to 1978, urban residential housing units were nationalized by the state, financed, and allocated through work unit (danwei 单位) at the operational level. For three decades, urban housing was considered as welfare benefit and its allocation was based on a set of criteria such as job rank, job seniority, and types of work unit. During that period, the majority of urban residents were assigned to a work unit, where people worked, lived, and received subsidized benefits such as free or low-rent housing, primary and secondary education, medical care, and welfare assistance. Chinese work units were often classified into three types: party/government institutions (dangzheng jiguan 党政机关); public institutions (shiye danwei 事业单位); and enterprises (qiye danwei 企业单位). Enterprises were further divided into state-owned enterprises (guoyou qiye 国有企业) and collectively-owned enterprises (jiti qiye 集体企业). Each work unit had a bureaucratic rank that supported its capacity to bargain with governments for resources on behalf of its employees. Work units constituted a hierarchy in which party/government institutions were ranked on the top and collectively-owned enterprises on the bottom (Brian 1994; Walder 1992). The strong dependence of workers on their work units and their identity became an important sign of social status and the main vehicle for social mobility (Lin \& Bian, 1991; $\mathrm{Wu}, 2001)$. Workers lived in the work unit ownership housing and were strongly dependent on housing from the state and its local government agencies.

The work unit housing was only offered to residents who had urban household registration status (hukou 户口). China has a dual system of household registration. It is an institutional arrangement to manage rural and urban areas by dividing people into rural residents and urban residents. Established in 1958 by Chairman Mao Zedong, hukou has been used as a means of social control and resource allocation from rural to urban areas, restricting labor mobility, and separating the country into rural and urban segments. Under this regulation, people enjoyed two different sets of entitlements. Urban residents who were full-time employees in work units had stable wage and subsidized welfare housing, whereas rural residents had no fixed income and no access to public housing, primarily relied on the crop harvest to make a living, and built the house on their own.

Old neighborhood housing was related to housing with deteriorated urban living conditions including both public welfare housing and private housing, even when the proportion of privately owned housing was marginal in urban areas (Lu \& Wang, 1996). Following the heavy industry development model, the state regarded that type of housing sector to be a non-productive sector of the economy and invested little resources in new housing construction resulting in 130 million urban dwellers having only $3.5 \mathrm{~m}^{2}$ of housing per person in 1981 (Kirkby, 1985). In addition to a lack of housing funds for new construction and/or maintenance, low rental income generated from the welfare housing system was not sufficient to cover repair costs (Kirkby, 1988). According to Kirkby (1988), the expense for public housing repair on average cost 2.1 Chinese currency (yuan 元) per $\mathrm{m}^{2}$, whereas the rental income was merely 1.09 yuan per $\mathrm{m}^{2}$ in 1977, one year before market-oriented reform was launched. The inadequacy of the rental income and lack of housing funding was responsible for housing stock degradation. Buildings in old neighborhoods had worse quality that were relatively older and made with inferior construction materials. Basic infrastructure that was relevant to the inhabitants' daily lives was poorly built so that qualities of sanitation, water pipes, electric coverage, telephone and internet network service were typically substandard. In addition, in these old neighborhoods there was limited open space that provided beautification of the area and recreational use.

Economic reform ended the state's monopoly of the urban residential housing system and triggered the private housing market, or commodity housing units. Following a trial of privatization reform of state-owned residential housing units over 100 cities, the first private housing development was founded in Shenzhen, China's Special Economic Zone, in 1980. Although the development of the commodity housing sector was limited in scope during the 1980s and early 1990s, it had grown exponentially since late 1990s. The milestone in China's housing reform was witnessed in 1998, when work units stopped developing and providing welfare housing for their employees, resulting in the households having to buy or rent in the private housing market. A boom in the private housing market boosted construction of new commercial apartment units. High-rise apartment towers, which included tens to hundreds of apartments in one building, were dispersed in varied locales throughout the country. Although the real estate market also provided high quality apartment housing, as well as villas targeted for high-income households, the common commercial apartment housing was now dominant among middle-class households.

Other than work unit housing, commercial apartment housing, and old neighborhood housing, there are other types of housing that are prevalent in urban areas These housing includes urban renewal housing, migration housing, and recently urbanized areas (Dongqianfang, 动迁房 or relocation housing). Urban renewal housing is related to rehabilitation and redevelopment of those communities which were located at edge of city, had land 
dispute, poor urban planning, and inadequate amenities (McCallum, 1993; Leaf, 1995). Residents in urban renewal areas usually did not have work unit affiliation, and/or could not afford the commercial housing at the market rate. Another type of housing was migrant housing. The significant rise of rural-to-urban migration has been prominent during China's economic transition. According to Chen (2011), rural migrant labor was estimated to be about 155 million in 2010. Despite the large scale migration, rural migrants were not integrated in urban housing reform, and their needs were largely overlooked (Solinger, 1999; Wang \& Murie, 2000). Migrants could not access bank mortgages for purchasing new commercial housing in many large cities because they were restricted to local residents with urban hukou. The secondary housing market, where older housing units were traded, the transaction often required the ownership of a local hukou. Although commercial housing is open for migrants, it is often not an option for most migrants who work for low-wage jobs. So, they typically rent directly from individual owners in urban cities, or from suburban farmers. Over time, the rising demand of migrants for housing and the lack of regulatory oversight contribute to the chaotic situation of the rental housing sector $(\mathrm{Wu}, 2004)$. As urbanization spreads, those farm lands at the edge of city were incorporated into urban planning. New apartments were built, named urbanized areas, and those former peasants were granted urban hukou and relocated away from their original homes.

\subsection{Local Political Participation in China}

There are two types of decision-making bodies in urban China at the local community levels: the Local People's Congress (LPC, or Difang renda 地方人大); and the urban Residents' Committee (RC, or Jumin weiyuanhui 居 民委员会).

The People's Congress (PC or Quanguo renda changweihui 全国人大常委会) is the legislative body in China, and has its local branches across the country - LPC. Unlike their higher-level counterparts which take part in lawmaking, such as National People's Congress or Provincial People's Congress, local legislatures primarily focus on amending legislation drafted by others and on providing a venue for concerned parties to work out differences (O'Brien, 2009). However, in big cities such as provincial capital city Guangzhou, LPC often initiated dozens of hearings to increase transparency and give the general public an opportunity to participate in lawmaking process. For instance, the LPC plays an active role in policy diffusion on issues such as consumer rights and protection of children in the local community (Cho, 2008; Naftali, 2009; Xia, 2007). Due to tight party control, there is a minimal electoral connection between the elected and those who elect them (Xia, 2007). Despite its low representation, the LPC acts as one of the two major state-backed legislative institutions at the bottom of political hierarchy in urban areas.

The urban Residents' Committee (RC) is the lowest level of the administrative hierarchy in China's cities, and has become the major state institution for the governance and management of urban neighborhood (Bing, 2012). Employees working in those RCs are paid by the state and serve as its designated liaisons within the neighborhood (Read, 2002). By law, the head of each RC is supposed to be directly elected by residents living within the community. Initially, the RC was established in the 1950s to assist work units at the grass roots level to implement Party and government policies, fulfill a number of administrative, social, political and policing duties issued by the government such as family-planning compliance and household registry roll (Chen, Lu \& Yang, 2007; Reed, 2000). In addition, the RCs also function as service providers such as listening to and acting on residents' suggestions and complaints and organizing social and civic activities for them. Through this system, the state is able to monitor and take in charge of neighborhood life. The size of RCs has geographic dispersal with approximately 2,500 RCs in Beijing, the Capital of China (Zhou, 2003). During the past decade, the central government has been striving for "community construction" along with the breakdown of danwei system. Although the contents of community construction vary from place to place, these areas were generally considered: community organizations; community service; community culture; community sanitation; community environment; and community public security (Yong, Ma \& Muhlhahn, 2009).

\subsection{Local Community Participation in China}

With the disintegration of the former work unit system, the RC has emerged to be the major grassroots self-governance institution that bridges the state and the mass population. According to the state-society theory, there are interactive relationships between the state apparatus and the formation of civil society, and these interactions promote political transformation (Bergere, 1997; Goldstein, 1995). Prior to the reform, the work unit played an important role in maintaining order and controlled the society on the behalf of the state. In comparison, the construction of private commercial housing separated the living space from workplace, and diversified the residential communities to accommodate people with different socioeconomic status. Even within a community with the same income level, people came from a wide range of backgrounds and became alienated from each 
other. Of the many functions the grassroots performed, the community organized cultural and festival events to unify the residents and energize the neighborhood. The activities were in various forms, from games and prizes, colorful arts show performance, food courts, children's zones, arts and crafts and cultural shows, as well as educational forums such as health fairs. As China's economy continues to sail to deeper reforms, the privatization of urban housing is expected to reshape the state-society relationship.

\subsection{The Middle Class}

There is no consistent definition of middle class in social science. The term has been defined according to many different criteria: a group of people whose income falls into certain medium range such as the second to the third quartile of income distribution (Johnson, 2004), or people who work in these five occupations such as party and state cadres, business managers, private entrepreneurs, professionals, and office staff (Lu, 2002), or finally, people who identify themselves subjectively as the middle class (Jennings and Stoker, 2004). According to the Organization for Economic Cooperation and Development (OECD), the middle class is one of the most widely recognized definitions, and is qualitatively described as "usually enjoying stable housing, healthcare, and educational opportunities for their children, reasonable retirement and job security, and discretionary income that can be spent on vacation and leisure pursuits" (Kharas, 2010). No matter which definition is used, the middle class is widely perceived as enjoying a relatively decent life style that is supported by a relatively higher income level with higher democratic attitudes (Tang, 2011).

\section{Method}

\subsection{Data and Sample}

This study used a cross-sectional, explanatory, correlational design. The data are from the 2005 China General Social Survey (CGSS), which is one of the few large scale social survey projects conducted in mainland China. As a national representative survey including adults aged 18 and above living in both rural and urban China, the CGSS was conducted annually 2003-2005 and biannually 2006-2010 through the joint efforts by Renmin University of China, Hong Kong Science and Technology University, and seven other top Chinese higher education institutions. By employing a multi-stage stratified random sampling method, the CGSS is representative of the general population at four stages: (1) 125 urban districts and rural counties were selected in the first stage; (2) four townships and city sub-districts were selected in the second stage; (3) two urban neighborhood communities and rural villager committees were selected in the third stage; and (4) ten households with one eligible household member each household were selected as survey respondents in the four stage. In order to keep abreast of rapid changes in Chinese society, the CGSS covers a wide range of topics such as income, education, employment, marriage and family, health care, insurance, attitudes, and opinions.

The 2005 CGSS was conducted with in-person interviews and a paper questionnaire. There were 10,372 respondents from 28 provinces responded this survey. Because the housing situation is very different between urban and rural areas, rural sample was excluded. As a result, the analytic sample restricted to urban respondents aged 18 years or above with 2,817 males and 3,229 females. Of the total sample, 1,364 lived in commercial housing apartments (22.56\%), 2,687 lived in work units (4.44\%), 1,094 lived in old neighborhood (18.09\%), and 901 lived in other types (14.90\%; urban renewal housing, migration housing, etc.).

\subsection{Measurements}

Dependent Variables. Two binary indicators for dependent variables were analyzed. The first assessed urban residents' political participation in local elections- as measured by a vote in the Local People's Congress (LPC), and a vote in Residents' Committee (RC). The measure of a vote in the LPC was assessed by asking, "Whether or not the respondent claimed to vote in the most recent LPC election?"; the measure of a vote in the RC was assessed by asking, "Whether or not the respondent claimed to vote in the most recent RC election?". The original responses were coded using three categories: $1=$ no vote, $2=$ involuntary vote required by local cadres, $3=$ voluntary vote. Categories 2 and 3 were combined and transformed into dichotomous variables: 1=vote regardless of being involuntary or voluntary, and $0=$ no vote.

Independent Variables. The variable of central interest is the respondent's current type of housing, which was coded into a 4 level categories: $1=$ commercial housing apartment, $2=$ work unit ownership housing, $3=$ old city neighborhood, $4=$ other types such as urban renewal projects, migrants' villages, and new relocation housing. The variables were converted into a set of dummy variables in the regression analysis, with living in old neighborhood serving as the reference group. When further conducting analysis among the subsample living in the commercial housing, another independent variable, an indicator of whether local community organized cultural or festival events was used. This indicator variable was dichotomously coded as 1=yes (either frequently 
or infrequently occurred) and $0=$ no.

Control variables. We included socio-demographic variables in the analyses, including age, gender, minority ethnicity, marital status, income, and education. Age was coded as a five-level categorical variable based on 10 -year age groups (1=younger than $30,2=30-39,3=40-49,4=50-59,5=60$ and older). Gender was dummy coded with male $=1$ and female $=0$. Minority status was treated as a dichotomous variable with 1 representing ethnic minority people (Mongol Chinese, Korean Chinese, etc.), and 0 indicating the majority Han Chinese. Marital status was coded with $1=$ married and $0=0$ other types. Education was measured as a 5 -level categorical variable: $1=$ no formal schooling, $2=$ =primary school, $3=$ =middle school, 4=high school or equivalent, and $5=$ college and above. Lastly, household income was coded as four levels: $1=$ the lowest $25 \%$ percentile, $2=$ the second lowest $25 \%$ percentile, $3=$ the third $25 \%$ percentile, and $4=$ the richest $25 \%$ percentile. The income was measured in Chinese currency (yuan).

\subsection{Analysis Plan}

The first step of analysis examined distributional differences among four subgroups: commercial apartment housing, work unit housing, old neighborhood, and other type of housing. The F-test from the Analysis of Variance (ANOVA) was employed to assess group differences in major characteristics. Second, a series of multivariate logistic regression models was used to examine the association between each housing indicator and each dependent variable with standard errors in robust form. Two indicators of political participation were estimated: "vote in Local People's Congress election", and "vote in Residents' Committee election". Third, the final analysis predicted local political participation among the subsample living in the commercial housing. Along with the main effect model, the interaction effects of age categories and the indicator of running cultural events were tested in order to explore age differences in the effects of having cultural events on residents' local political participation. All models were controlled for socio-demographic characteristics (age, gender, minority status, marital status, income and education). The odds ratio and $95 \%$ confidence interval were reported along with the significance level.

Because the direct use of categorical variables in multivariate regression analysis often caused confusion in terms of interpretation, the commonly used strategies- dummy coding were adopted (Aginis, 2003). In order to compare the effects of each category of the predictor variable, one specific group of the variable was designated as the reference group and compared to other groups of the variable. For example, in relation to types of housing, living in commercial housing unit, living in work unit, living in other type of housing was compared to the reference category- living in old neighborhood. The old neighborhood housing type was selected as reference group because the ages of housing units in old neighborhood were oldest among all housing types. When interpreting multivariate regression results, all of the estimated odds ratios for the different categories of the housing variable were calculated in relation to those who were currently living in old neighborhoods. All statistical analyses were performed using the statistical software package SPSS 22.0.

\section{Results}

\subsection{Characteristics of Urban Residents}

Table 1 presents the descriptive statistics of the sample, and compared group differences among urban residents living in four different types of housing: commercial apartment buildings, work unit housing, old neighborhood, and other type of housing.

On average, the voting rates for the Local Political Congress election and the Residents' Committee election in this sample were $26.93 \%$ and $30.37 \%$, respectively. The proportions of people voting in the LPC were $25.22 \%$ in commercial housing, $22.78 \%$ in work unit housing, $30.26 \%$ in old neighborhoods, and $37.85 \%$ in other type of housing. The proportions of voting in the RC were also low across four types of housing: between $29.48 \%$ (in working unit) and $32.30 \%$ (in other type of housing). ANOVA tests indicated that statistically significant differences existed in local People's Congress election among four housing types $(\mathrm{p}<.001)$.

Demographic characteristics of study participants were also presented in Table 1. On average the participants were 43 years old, with $18.31 \%$ between $18-29,22.94 \%$ between $30-39,22.16 \%$ between $40-49,17.22 \%$ between 50-59, and 19.37\% 60 and older. After breaking down the data into five age subgroups, the subgroup aged 30-39 emerged as the largest group in commercial housing $(22.87 \%)$, work unit housing $(22.63 \%)$ and other type of housing (27.41\%), whereas the largest group was older and aged 40-49 for those living in old neighborhood (24.13\%). Fewer than 50\% were males, fewer than $10 \%$ belonged to ethnic minority, and about $80 \%$ were married. In terms of income and education, residents living in commercial housing had the highest socioeconomic status. For educational attainment, the proportion of college-educated residents accounted for 
$22.60 \%$ in commercial housing, compared to $21.66 \%$ in work unit, $11.88 \%$ in old neighborhood, and $10.88 \%$ in other types of housing. For income distribution, the proportion of residents whose income belonged to the richest $25 \%$ percentile accounted for $51.98 \%$ in commercial housing, $40.83 \%$ in work unit, $36.75 \%$ in old neighborhood, and $36.07 \%$ in other types of housing units.

Table 1. Descriptive statistics of the sample, Chinese general social survey 2005

\begin{tabular}{|c|c|c|c|c|c|}
\hline & $\begin{array}{l}\text { Commercial } \\
\text { Housing } \\
\text { Mean (sd) }\end{array}$ & $\begin{array}{l}\text { Work Unit } \\
\text { Housing } \\
\text { Mean (sd) }\end{array}$ & $\begin{array}{l}\text { Old } \\
\text { Neighborhood } \\
\text { Mean (sd) }\end{array}$ & $\begin{array}{l}\text { Other Type } \\
\text { Mean (sd) }\end{array}$ & $\begin{array}{l}\text { ANOVA } \\
\text { (p-value) }\end{array}$ \\
\hline \multicolumn{6}{|l|}{$\mathrm{DV}=$ Political participation } \\
\hline Vote in LPC (yes=1) & $25.22 \%(.43)$ & $22.78 \%(.42)$ & $30.26 \%(.46)$ & $37.85 \%(.48)$ & $<.001$ \\
\hline Vote in $\mathrm{RC}$ (yes=1) & $29.99 \%(.46)$ & $29.48 \%(.46)$ & $31.44 \%(.46)$ & $32.30 \%(.47)$ & .348 \\
\hline \multicolumn{6}{|l|}{$\mathrm{IV}=$} \\
\hline $\begin{array}{l}\text { Whether have } \\
\text { community-led events }\end{array}$ & $25.14 \%(.43)$ & $31.78 \%(.46)$ & $24.49 \%(.43)$ & $28.74 \%(.45)$ & $<.001$ \\
\hline \multicolumn{6}{|l|}{ Age } \\
\hline Actual age & $43.99(15.67)$ & $45.45(15.46)$ & $44.71(15.35)$ & $43.23(15.08)$ & .001 \\
\hline \multicolumn{6}{|l|}{ Breakdown into 5 categories } \\
\hline $18-29$ & $20.23 \%(.40)$ & $16.93 \%(.37)$ & $18.74 \%(.39)$ & $18.98 \%(.39)$ & .066 \\
\hline $30-39$ & $22.87 \%(.42)$ & $22.63 \%(.42)$ & $20.11 \%(.40)$ & $27.41 \%(.45)$ & .002 \\
\hline $40-49$ & $21.70 \%(.41)$ & $21.44 \%(.41)$ & $24.13 \%(.43)$ & $22.64 \%(.42)$ & .312 \\
\hline $50-59$ & $16.28 \%(.37)$ & $17.94 \%(.38)$ & $18.37 \%(.38)$ & $15.09 \%(.36)$ & .127 \\
\hline $\begin{array}{l}60+ \\
\text { (reference group) }\end{array}$ & $18.91 \%(.39)$ & $21.06 \%(.41)$ & $18.65 \%(.38)$ & $15.87 \%(.36)$ & .006 \\
\hline Male $($ yes $=1)$ & $46.85 \%(.49)$ & $46.04 \%(.49)$ & $47.17 \%(.49)$ & $47.17 \%(.49)$ & .888 \\
\hline \multicolumn{6}{|l|}{ Ethnic Minority (yes=1) } \\
\hline & $3.67 \%(.18)$ & $5.47 \%(.23)$ & $7.13 \%(.26)$ & $1.89 \%(.14)$ & $<.001$ \\
\hline Married (yes=1) & $79.03 \%(.41)$ & $79.46 \%(.40)$ & $77.42 \%(.42)$ & $85.35 \%(.35)$ & $<.001$ \\
\hline \multicolumn{6}{|l|}{ Income } \\
\hline Actual income (yuan) & $\begin{array}{l}30665.47 \\
(34424.24)\end{array}$ & $\begin{array}{l}25789.05 \\
(29637.57)\end{array}$ & $\begin{array}{l}26141.49 \\
(39048.65)\end{array}$ & $\begin{array}{l}24874.82 \\
(36256.03)\end{array}$ & $<.001$ \\
\hline \multicolumn{6}{|l|}{ Breakdown into 5 categories } \\
\hline $\begin{array}{l}\text { Poorest } 25 \% \\
\text { (reference group) }\end{array}$ & $7.12 \%(.26)$ & $9.48 \%(.29)$ & $18.80 \%(.39)$ & $16.29 \%(.37)$ & $<.001$ \\
\hline $2^{\text {nd }} 25 \%$ & $15.37 \%(.36)$ & $21.41 \%(.41)$ & $20.99 \%(.41)$ & $22.83 \%(.42)$ & $<.001$ \\
\hline $3^{\text {rd }} 25 \%$ & $30.50 \%(.46)$ & $32.97 \%(.47)$ & $26.24 \%(.44)$ & $29.37 \%(.46)$ & .001 \\
\hline Richest $25 \%$ & $51.98 \%(.49)$ & $40.83 \%(.49)$ & $36.75 \%(.48)$ & $36.07 \%(.48)$ & $<.001$ \\
\hline \multicolumn{6}{|l|}{ Education } \\
\hline $\begin{array}{l}\text { No schooling } \\
\text { (reference group) }\end{array}$ & $4.48 \%(.21)$ & $5.70 \%(.23)$ & $8.14 \%(.27)$ & $5.99 \%(.24)$ & .002 \\
\hline Primary & $11.15 \%(.31)$ & $12.45 \%(.33)$ & $15.81 \%(.36)$ & $21.09 \%(.41)$ & $<.001$ \\
\hline Junior & $27.29 \%(.44)$ & $27.48 \%(.45)$ & $33.36 \%(.47)$ & $35.52 \%(.48)$ & $<.001$ \\
\hline High school & $34.48 \%(.47)$ & $32.70 \%(.47)$ & $30.80 \%(.46)$ & $26.53 \%(.44)$ & .001 \\
\hline College & $22.60 \%(.42)$ & $21.66 \%(.41)$ & $11.88 \%(.32)$ & $10.88 \%(.31)$ & $<.001$ \\
\hline
\end{tabular}

Note: Means and standard deviations (in parentheses) are reported for continuous or dummies variables. The p-value is from two-tailed tests. 


\subsection{Multivariate Analysis: Predicting Local Political Participation}

Table 2. Logistic regression for local political participation (CGSS 2005)

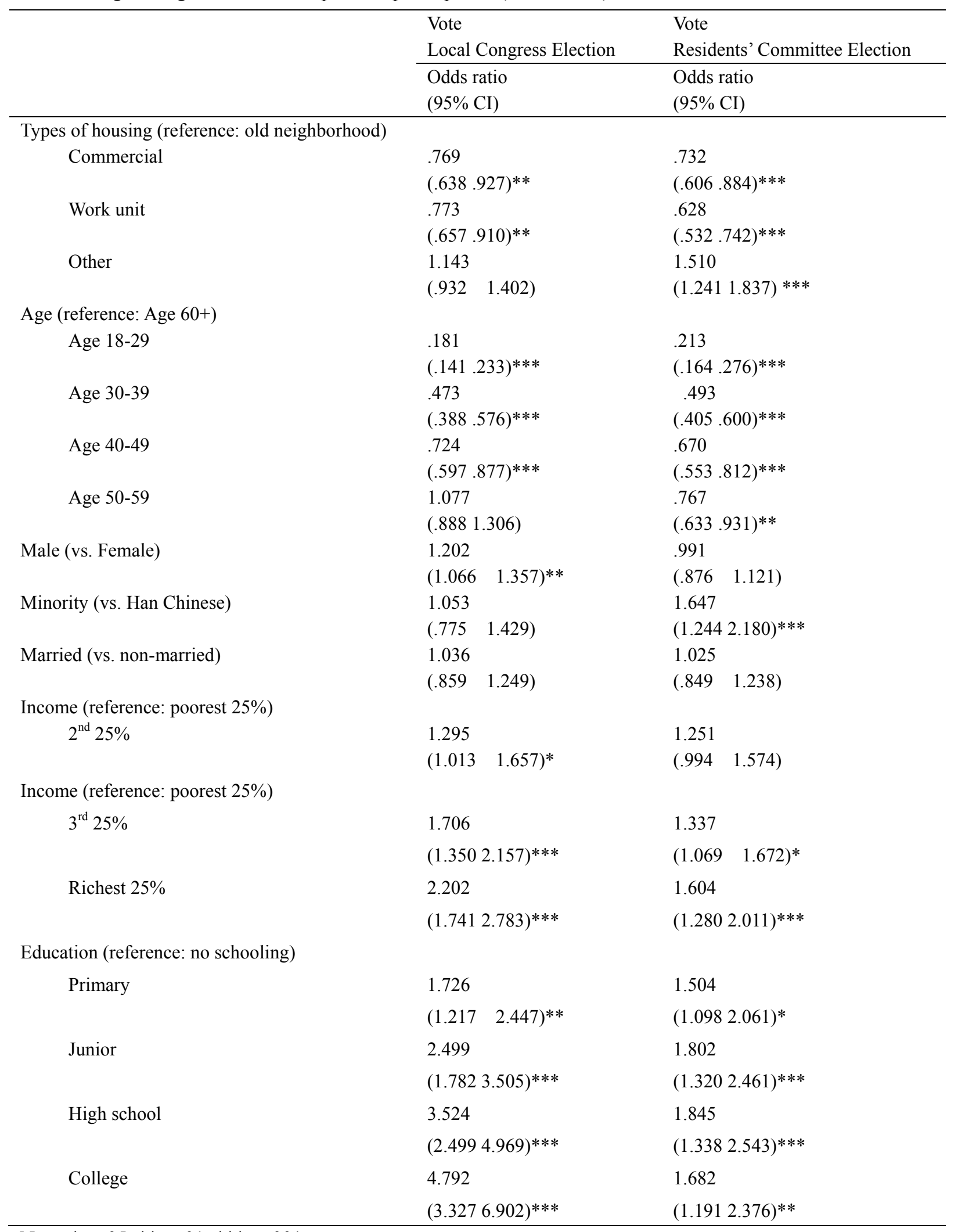

Note: ${ }^{*} \mathrm{p}<.05 ; * * \mathrm{p}<.01 ; * * * \mathrm{p}<.001$ 
Table 2 displays the results from multivariate logistic regressions. The results suggest that those living in newly purchased commercial housing reported statistically significant lower levels of political participation in the LPC election and the RC election. The same associations were also observed among those living in work unit housing.

The first column in Table 2 presents the results of the effects of housing types on local political participation. Compared to those participants living in old neighborhood, residents living in commercial housing were $23 \%$ less likely to vote in $\mathrm{LPC}$ election ( $\mathrm{p}<0.01, \mathrm{OR}=0.769,95 \% \mathrm{CI}=0.638$ to 0.927 ), and $27 \%$ less likely to vote in $\mathrm{RC}$ election $(\mathrm{p}<0.001, \mathrm{OR}=0.732,95 \% \mathrm{CI}=0.606$ to 0.884$)$, respectively. As for other socio-demographic characteristics, young people were significantly less likely to vote in elections, and the likelihood of voting increased linearly as ages increased. Compared to female residents, males were significantly more likely to vote in elections. Compared with the poorest, the likelihood of voting was linearly growing as income increased. Compared with people with no schooling, the likelihood of voting was also growing as educational attainment increased. Residents belonging to the richest $25 \%$ and having college education had the highest likelihood of voting in local elections.

4.3 Multivariate Analysis: Predicting Voting in Residents' Committee among the Commercial Housing Subsample

Table 3. Logistic regression for vote in residents' committee election among the subsample residents living in commercial housing (CGSS 2005)

\begin{tabular}{|c|c|c|}
\hline \multirow{3}{*}{ IV: Community-led Cultural Events } & Main effect model & Interaction model \\
\hline & Odds ratio $(95 \% \mathrm{CI})$ & Odds ratio $(95 \% \mathrm{CI})$ \\
\hline & $\begin{array}{l}2.629 \\
(1.9673 .514)^{* * *}\end{array}$ & $\begin{array}{l}1.898 \\
(1.0553 .415)^{*}\end{array}$ \\
\hline Age (reference: Age $60+$ ) & & \\
\hline $18-29$ & $\begin{array}{l}.219 \\
(.122 .392)^{* * *}\end{array}$ & $\begin{array}{l}.189 \\
(.094 .378)^{* * *}\end{array}$ \\
\hline $30-39$ & $\begin{array}{l}.487 \\
(.318 .746)^{* * *}\end{array}$ & $\begin{array}{l}.337 \\
(.200 .569)^{* * *}\end{array}$ \\
\hline $40-49$ & $\begin{array}{ll}.655 & \\
(.429 & 1.000)^{*}\end{array}$ & $\begin{array}{l}.715 \\
(.4411 .158)\end{array}$ \\
\hline $50-59$ & $\begin{array}{l}.707 \\
(.464 \\
(1.078)\end{array}$ & $\begin{array}{l}.594 \\
(.355 .995)^{*}\end{array}$ \\
\hline Interactions & & \\
\hline $18-29 *$ Cultural Event & - & $\begin{array}{l}1.504 \\
(.551 \quad 4.103)\end{array}$ \\
\hline 30-39*Cultural Event & - & $\begin{array}{ll}3.323 & \\
(1.394 & 7.918) * *\end{array}$ \\
\hline 40-49*Cultural Event & - & $\begin{array}{ll}.750 & \\
(.329 & 1.709)\end{array}$ \\
\hline $50-59 *$ Cultural Event & - & $\left.\begin{array}{l}1.633 \\
(.692 \\
3.852\end{array}\right)$ \\
\hline Male (vs. Female) & $\left.\begin{array}{ll}1.002 & \\
(.761 & 1.320\end{array}\right)$ & $\begin{array}{l}1.002 \\
(.759\end{array}$ \\
\hline Minority (vs. Han Chinese) & $\begin{array}{l}1.012 \\
(.460\end{array}$ & $\begin{array}{l}.911 \\
(.396 \quad 2.093)\end{array}$ \\
\hline Married (vs. non-married) & $\begin{array}{l}1.116 \\
(.708 \\
1.758)\end{array}$ & $\begin{array}{l}1.114 \\
(.706 \\
1.755)\end{array}$ \\
\hline
\end{tabular}




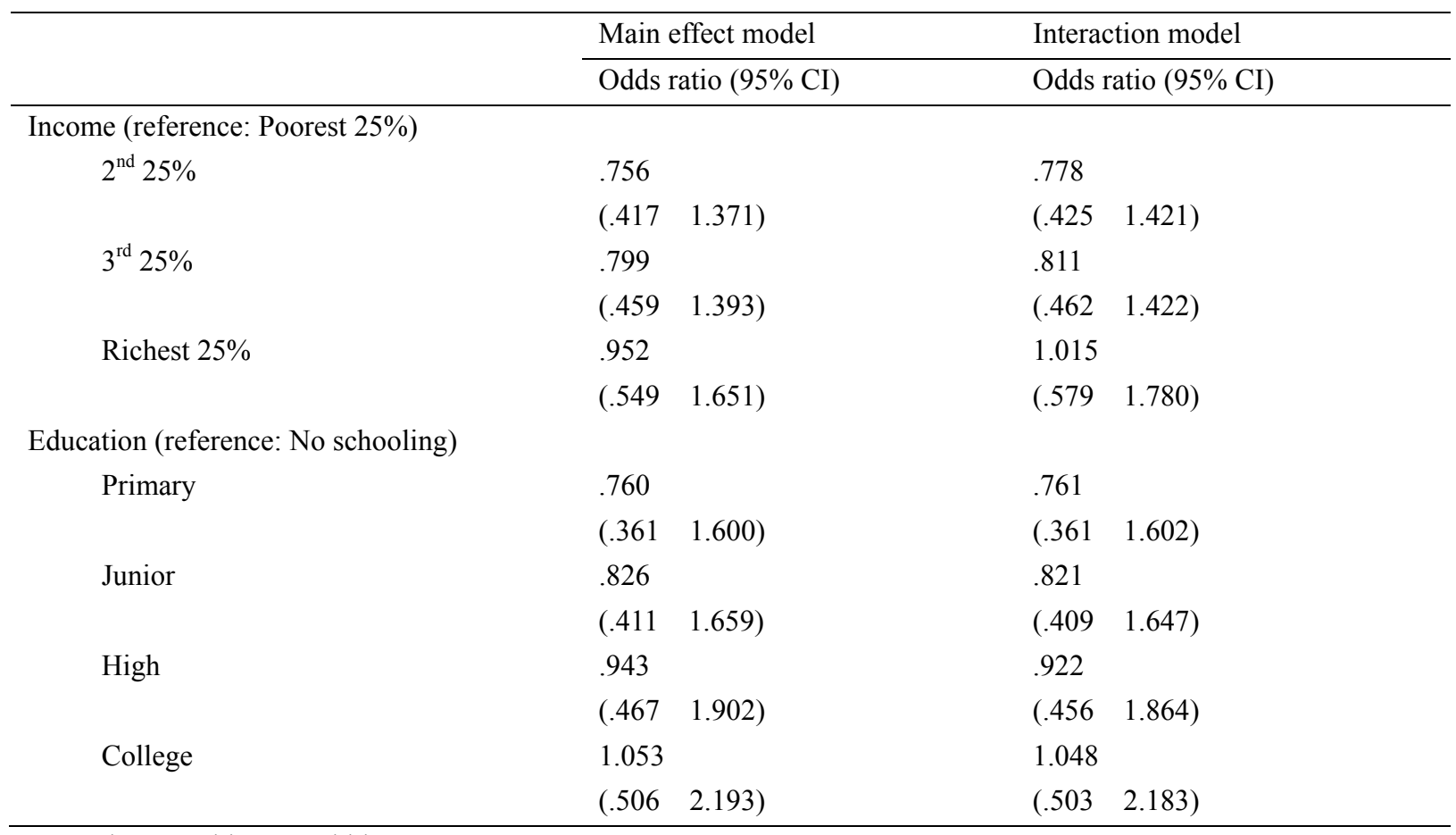

Note: ${ }^{*} \mathrm{p}<.05 ; * * \mathrm{p}<.01 ; * * * \mathrm{p}<.001$

Table 3 presented the multivariate results for predicting voting in the RC election among the subsample who lived in commercial housing. By comparing results with and without interaction terms, the effect of community-initiated cultural events on local political participation was investigated. Adjustments for socio-demographic factors were considered. The main effect model showed that community-level cultural or festival events significantly increased the likelihood of participating in elections of RC among people living in commercial housing. The probability of participation increased as people became older, had more income and educational attainment. In comparison, the interaction model further strengthened the main results that community-led cultural events played a positive role in promoting voting in RC. After investigating each interaction term between age subgroup and cultural event, we found that residents aged 30-39 were in the only subgroup who indicated the strongest likelihood of voting in $\mathrm{RCs}(\mathrm{p}<.01, \mathrm{OR}=3.323,95 \% \mathrm{CI}=1.394 \mathrm{TO} 7.918)$.

\section{Discussion}

Previous studies of democratic participations among urban Chinese middle class indicate mixed findings (Chen \& Lu, 2006; Chen \& Dickson, 2008; Tang, Woods, \& Zhao, 2009). This study extended existing knowledge to the group living in newly erected commercial housing units. Rapid housing reform in urban China has triggered the onset of new residential properties with private ownership, which diversified the neighborhood and initiated grassroots self-governance institution. Based on a nationally representative dataset of China, we examined the dynamic relationship between housing types and democratic participations among urban Chinese residents. The research findings supported two hypotheses that the likelihood of voting in local elections varied across different types of housing units; and community-led cultural or festival events played an important role in determining local political participation for residents living in commercial housing.

Consistent with the first hypothesis, urban residents living in commercial housing units had the lowest likelihood of voting in the local People's Congress and the local Residents' Committee, compared to those living in old neighborhoods. This finding contributes to the literature of modernization theory of political development in the following ways. First, the Chinese middle class living in newly-built properties seems to be less democratically oriented compared to their counterparts living in other types of housing units. The empirical evidence indicated that the middle class was not necessarily enthusiastic about political democratization. The modernization theory that argues economic development will promote a strong demand for democracy among the middle class, was not directly testified from this empirical evidence. Second, although the direct association was not observed, the findings identified the subgroup of the middle class who were more in favor of democratic actions. Those middle class residents were in their 30 s, college educated, and had high income.

The results also supported the second hypothesis that community-organized cultural or festival events can 
significantly enhance the voting in local elections among residents living in commercial housing. This empirical evidence supports the state-society theory by highlighting the interactive relationships between the Residents' Committee and residents. These informal community bonds in China can predict more democratic participation for decision-making. With rapid urbanization and economic transition, former communities became disintegrated and new communities are still under construction. As a consequence, new residents have a sense of being less connected to the community, and less prepared for local political participation. This study implies that, if the state can invest more in community-level activities and engage the residents to a large scale, the state will ultimately witness an increase in the middle class's support for more democratic political change as the middle class feel the state is concerned about their socioeconomic wellbeing.

It is important to bear in mind that there are several limitations in this study. First, as is inherent in any cross-sectional study, it is impossible to draw causal inferences between housing types and local political participation. Although a carefully selected set of controlling variables can improve the efficiency of the estimate, we can not verify that we have controlled for all the confounders or eliminate the reverse causality. That is, it is plausible that residents in favor of low democratic actions tend to purchase newly built commercial housing units Second, due to the cross-sectional nature of the data, this study did not examine whether changing in housing types are associated with changes in democratic actions. Further longitudinal study will help strengthen the link between housing types and democratic participation. Third, the dichotomous measures of voting in local elections can be narrow operationalization of local political participation. Other than voting in these two important offices, measurements such as rally, petition and protests can also be considered for local political participation in the future study. Fourth, we did not assess other types of community-initiated activities. As discussed earlier, the content of "community construction" contained six broad areas, and community culture was just one out of six. Future study can investigate the link between other community-based events and democratic actions. Nevertheless, this study contributes to the broad literature of the connection between the rising middle class during economic transition and political democratization by examining an understudied area - residential housing units.

\section{Conclusion}

This study indicates that voting in local political elections significantly varied among residents living in different types of housing units. Findings from this project suggest that community-initiated activities can prevent further alienation and withdrawal from democratic participation among urban Chinese. Young, college-educated, high-income middle class can take the lead to reenergize the newly formed communities. Since the rates of voting in local political elections are still low in urban China, policies should be promoted that invest interactive activities and events at the community level to unite people from diverse background and build strong ties between the community and individuals. Furthermore, policies toward educational investments are particularly important because a growing educated middle class contributes not only as productive labor force and major engine of consumer spending, but also emerges as change agents for local political participation. Services should be developed that can upgrade the poor infrastructure and eliminate deterioration in old neighborhoods. Although residents in old neighborhood housing were relatively older, they were more politically active in local elections. The shift from living in old neighborhoods and/or former employer-provided housing to privately owned commercial housing will require more community-based and high-level government work in order to promote large-scale democratic participation.

\section{Acknowledgments}

The authors declared no potential conflicts of interest with respect to the research, authorship, and/or publication of this article.

The authors received no financial support for the research, authorship, and/or publication of this article.

\section{References}

Aguinis, H. (2003). Regression analysis for categorical moderators: Methodology in the social sciences. New York: The Guilford Press.

Barro, R. (1999). Determinants of democracy, Journal of Political Economy, 107(6), 158-183. http://dx.doi.org/10.1086/250107

Barton, Dominic, Yougang, C., \& Amy, J. (2013). Mapping China's middle class, McKinsey Quarterly. Retrieved from http://www.mckinsey.com/insights/consumer_and_retail/mapping_chinas_middle_class

Bergere, M. C. (1997). Civil society and urban change in Republican China, The China Quarterly, 150, 28-30. http://dx.doi.org/10.1017/S0305741000052498 
Bian, Y. (1994). Work and inequality in urban China. Albany, New York: SUNY Press.

Bing, N. C. (2012). The Residents' Committee in China's political system: Democracy, stability, mobilization. Issues \& Studies, 48(2), 71-126.

Boix, C., \& Stokes, S. C. (2003). Endogenous democratization, World Politics, 55(4), 517-549. http://dx.doi.org/10.1353/wp.2003.0019

Bollen, K. (1983). World system position, dependency, and democracy: the cross-national evidence. American Sociological Review, 48(4), 468-479.

Bourdieu, P. (1997). The forms of capital. In A. H. Halsey, P. Brown, \& A. S. Wells (Eds.), Education: Culture, economy, society (pp. 45-58). Oxford: Oxford University Press.

Chen, J., \& Lu, C. (2006). Does China's middle class think and act democratically? Attitudinal and behavioral orientations toward urban self-government. Journal of Chinese Political Science, 11(2), 1-20.

Chen, J., Lu, C., \& Yang, Y. (2007). Popular support for grassroots self-government in urban China: Findings from a Beijing survey. Modern China, 33(4), 505-528.

Chen, J., \& Dickson, B. (2008). Allies of the state: Democratic support and regime support among China's $\begin{array}{llll}\text { private } & \text { 78ntrepreneurs. The }\end{array}$ http://dx.doi.org/10.1017/S0305741008001124

Chen, J., \& Lu, C. (2011). Democratization and the middle class in China: The middle class's attitudes toward democracy. Political Research Quarterly, 64(3), 705-719. http://dx.doi.org/10.1177/1065912909359162

Chen, Y. (2011). Rural migrants in urban China: Characteristics and challenges to public policy. Local Economy, 26, 325-336.

Cho, Y. N. (2008). Local People's Congresses in China: Development and transition. New York: Cambridge University Press.

Coleman, J. (1997). Social capital in the creation of human capital. In A. H. Halsey, P. Brown, \& A. S. Wells (Eds.), Education: Culture, economy, society (pp. 80-95). Oxford: Oxford University Press.

Doepke, M., \& Zilibotti, F. (2007). Occupational choice and the spirit of Capitalism. NBER Working Paper 12917. National Bureau of Economic Research Inc., Cambridge, MA.

Forest, R., \& Yip, N. M. (2007). Neighborhood and neighboring in contemporary Guangzhou. Journal of Contemporary China, 16(50), 47-64.

Fukuyama, F. (1993). Capitalism and democracy: The missing link. In L. Diamond \& M. F. Plattner (Eds.), Capitalism, socialism, and democracy revisited (pp. 4-105). Baltimore: The Johns Hopkins University Press.

Goldstein, S. M. (1995). China in transition: The political foundations of incremental reform. The China Quarterly, 114, 1105-1131. http://dx.doi.org/10.1017/S0305741000004756

Glassman, R. (1995). The middle class and democracy in socio-historical perspective. Leiden: E. J. Brill Press.

Grootaert, C. (1998). Social capital: The missing link? Washington, D.C., The World Bank, Social Development Family, Environmentally and Socially Sustainable Development Network. Retrieved from http://siteresources.worldbank.org/INTSOCIALCAPITAL/Resources/Social-Capital-Initiative-Working-Pap er-Series/SCI-WPS-03.pdf

Gui, Y., Ma, W., \& Muhlhahn, K. (2009). Grassroots transformation in contemporary China. Journal of Contemporary Asia, 39(3), 400-423.

Hefele, P., \& Dittrich, A. (2011). China's middle class: A driving force for democratic change or guarantor of the status quo? KAS International Reports. Retrieved March 10, 2015, from http://www.kas.de/wf/doc/kas_29625-544-2-30.pdf?111205131951

Huang, Y. (2012). Low-income housing in Chinese cities: Policies and practices. The China Quarterly, 212, 941-964. http://dx.doi.org/10.1017/S0305741012001270

Huntington, S. (1991). The third wave: Democratization in the late Twentieth Century. Norman: University of Oklahoma Press.

Hurtado, R. (2014). China's middle class: Content in the "middle income stratum" or seeds of political change? China Studies Working Paper Series, Johns Hopkins School of Advanced International Studies. Retrieved 
from https://www.sais-jhu.edu/sites/default/files/China-Studies-Working-Paper-2014-Hurtado.pdf

Jennings, K., \& Stoker, L. (2004). The effects of social class identification on participatory orientations towards government. British Journal of Political Science, 34(3), 469-495.

Johns, D. (1998). Democratization, civil society, and illiberal middle class culture in Pacific Asia. Comparative Politics, 30(2), 147-169.

Johnson, A. (2004). Chinese middle class attitudes towards international affairs: Nascent liberalization? The China Quarterly, 179(3), 603-628.

Kharas, H. (2010). The emerging middle class in developing countries. Organization for Economic Cooperation and Development (OECD) Center Working Paper. Retrieved March 10, 2015, from http://www.oecd.org/dev/44457738.pdf

Kirkby, R. J. R. (1985). Urbanization in China: Town and country in a developing economy 1949-2000 AD. New York: Columbia University Press.

Kirkby, R. J. R. (1988). Urban housing policy after Mao. In Feuchtwang, Stephan, A. Hussain, \& T. Pairault (Eds.), Transforming China's economy in the Eighties. Boulder, Colorado: Westview Press.

Leaf, M. (1995). Inner city redevelopment in China: Implication for the City of Beijing. Cities, 12(3), 149-162.

Lin, N., \& Bian, Y. (1991). Getting ahead in urban China. American Journal of Sociology, 97, 657-688.

Londregan, J. B., \& Poole, K. T. (1996). Does high income promote democracy? World Politics, 49(1), 1-30. http://dx.doi.org/10.1353/wp.1996.0024

Lu, X., \& Qiming, W. (1996). Beijing courtyard housing. Beijing: China's Construction Industry Publishing Co.

Lu, X. (2002). Dandai zhongguo shehuijiecen yuanju baogao. Beijing: Social Science Literature Publisher.

McCallum, D. (1993). Renewal of older housing areas in Shanghai; Some recent small-scale projects. China City Planning Review, 2, 1-10.

Muller, E. N. (1997). Economic determinants of democracy. In M. I. Midlarsky (Ed.), Inequality, democracy, and economic development (pp. 133-155). New York: Cambridge University Press.

Naftali, O. (2009). Empowering the child: Children's rights, citizenship and the state in contemporary China. The China Journal, 61, 75-85.

O’Brien, K. (2009). Local People's Congresses and governing China. China Journal, 61, 131-141.

Portes, A. (1998). Social capital: Its origins and applications in modern sociology. Annual Review of Sociology, 24, $1-24$.

Putnam, R. (1993). The prosperous community: Social capital and public life. The American Prospect, 4(13), $35-42$.

Putnam, R. (1996). Who killed civic America. Prospect, 66-72.

Putnam, R. (2000). Bowling alone - The collapse and revival of American community. New York: Simon \& Schuster Press.

Read, B. L. (2000). Revitalizing the State's urban 'nerve tips'. The China Quarterly, 163, 806-820. http://dx.doi.org/10.1017/S0305741000014673

Read, B. L. (2002). Beijing's urban Residents' Committees as a case of grassroots administrative engagement: Using quantitative data to augment qualitative findings. Retrieved from http://mumford.albany.edu/chinanet/events/past_conferences/conferences/Read.pdf

Solinger, D. J. (1999). Contesting citizenship in urban China: Peasant migrants, the state, and the logic of the market. Berkeley: University of California Press.

Tang, M., Woods, D., \& Zhao, J. (2009). The attitude of Chinese middle class towards democracy. Journal of Chinese Political Science, 14(1), 81-95.

Tang, M. (2011). The political behavior of the Chinese middle class. Journal of Chinese Political Science, 16, 373-387.

Tomba, L. (2005). Residential space and collective interest formation in Beijing's housing disputes. The China Quarterly, 184, 934-951. http://dx.doi.org/10.1017/S0305741005000573

Unger, J. (2006). China's conservative middle class. Far Eastern Economic Review, 169(3), 17-31. 
United Nations. (2014). World urbanization prospects: The 2014 revision. Department of Economics and Social Affairs, the United Nations. Retrieved March 10, 2015, from http://esa.un.org/unpd/wup/Highlights/WUP2014-Highlights.pdf

Walder, A. G. (1992). Property rights and stratification in Socialist redistributive economies. American Sociological Review, 57, 524-539.

Wang, Y., \& Murie, A. (2000). Social and spatial implications of housing reform in China. International Journal of Urban and Regional Research, 24(2), 397-417.

Wu, X. (2002). Work units and income inequality: The effect of market transition in urban China. Social Forces, 80, 1069-1099. http://dx.doi.org/10.1353/sof.2002.0013

Wu, W. (2004). Sources of migrant housing disadvantage in urban China. Environment and Planning, 36, 1285-1304.

Xia, M. (2007). The People's Congresses and governance in China: Toward a network model of governance. London: Routledge Press.

Zhou, J. W. (2003, October 22). The percent of direct election of Residents' Committees is increasing, Beijing's community democracy is making progress. Beijing Evening News.

\section{Copyrights}

Copyright for this article is retained by the author(s), with first publication rights granted to the journal.

This is an open-access article distributed under the terms and conditions of the Creative Commons Attribution license (http://creativecommons.org/licenses/by/3.0/). 